Sia Spiliopoulou Åkermark

\title{
THE RISE AND FALL OF INTERNATIONAL LAW
}

Martti Koskenniemi (2002): The Gentle Civilizer of Nations: The Rise and Fall of International Law 1870-1960. Cambridge University Press.

$\mathbf{M}_{\text {different ways and fills many different functions. It is history }}^{\text {artti Koskenniemi's recent book can be described in many }}$ of ideas, history of science, lengthy and detailed biographies of a large number of (male) international lawyers but also quietly - almost hidden - a reformist agenda for the future of international law. It attempts answering the question of why international law came to be "depoliticized and marginalized, as graphically illustrated by its absence from the arenas of today's globalization struggles, or turned into a technical instrument for the advancement of the agendas of powerful interests or actors in the world scene". In the words of the author "this books examines the rather surprising hold that a small number of intellectual assumptions and emotional dispositions have had on international law". ${ }^{1}$ Those assumptions and dispositions are summarised as "a sensibility about matters international in the late nineteenth century as an inextricable part of the liberal and cosmopolitan movements of the day". From this moment on, the word "liberal" appears in almost every page of at least all the most recently 
written parts of book. ${ }^{2}$ I will return to a discussion on "liberalism" below.

The book consists of six chapters dealing with the founding of and the ideology behind the Institut de droit international and its role in legitimizing colonial imperialism (chapters 1 and 2); German legal traditions ranging from historicism to the formalism and science approach to law as represented by Kelsen (chapter 3); the French sociological school which based its internationalism and cosmopolitanism on a sense of "solidarity" without however being able to surpass the references to "the idea", and the idea was France (chapter 4); a whole chapter on Hersch Lauterpacht (chapter 5); and ending with chapter 6 on the impact of Carl Schmitt, Hans Morgenthau and "the turn to 'international relations" mainly among American international lawyers. Final conclusions are found in an epilogue which, as we will see below, does not restrict itself to the formal time frame of the book (1870-1960).

Two "intuitions" have guided this temporal delimitation of the examination (1870-1960), the first being the institutionalization and professionalization of international law in the late 19th century and the second that "whatever began at that time come to an effective (if not formal) end sometime around 1960". "So this is the rise and fall of international law. But this "intuition" is qualified by the rather esoteric phrase "the international law that "rises" and "falls" in this book is, then, not a set of ideas - for many such ideas are astonishingly alive today - nor of practices, but a sensibility that connotes both ideas and practices but also involves broader aspects of the political faith, image of self and society, as well as the structural constraints within which international law professionals live and work". Reading this phrase in the very second page of the book leaves one in a perplexed state so familiar to much of post-modern writing. Everything is a whole, constructed by all surrounding factors and historical contingencies. It does not make more sense than so until one gets to the epilogue. International law remains a "useful diplomatic language and an honorable aspect of professional education at law schools". ${ }^{4}$ The civilizing project in the minds of the men of 1873 has failed and what remains is "the gap between the recurrent reform projects and blueprints about 'governance' and control, and the reality of picking up the per diem from the latest 
caucus meeting in Geneva or New York". In Koskenniemi's view international law does not have the ability to articulate political visions and critiques, and has simply become the reaffirmation of power. So far, we recognize the touch of irony in the words chosen, but now there are two new things which are not so readily visible in earlier writings of Koskenniemi. There is the impatience and longing for a reformist agenda, making use of the latent ability to articulate existing transformative commitment in the language of rights and duties. Second, there is, for the first time really in Koskenniemi's writings, an attempt to offer a theory and method for doing this. While his From Apology to Utopia (1989) not only remained static - something admitted by the author in the introduction to his new book - but more importantly, failed giving us any guidance on how to transgress the pendulum between power legitimation and idealism, the new work suggests that there may be a way out.

\section{The Way Out}

The way out is "the culture of formalism". ${ }^{5}$ However, the culture of formalism is not much more defined at this stage. We can understand more about the "culture of formalism" by what is described as its opposite. Following a longstanding tradition of conceptual analysis of polemical notions, opposites, we can easily see that Koskenniemi is mostly concerned by the predominantly American "culture of dynamism". Formalism cannot any longer be understood as a focus on the questions of "black and white legal validity". This would bring us back to the Kelsenian mistake before the Second World War. The purpose of formalism is to function as resistance to power, a basis of accountability, openness and equality and of overcoming the irreducibility of difference. The "culture of dynamism" by contrast has a completely different agenda: that of effectiveness, optimization and compliance with regard to what is predetermined as valid law. Thereby it plays easily in the hands of the powerful. What are the implications of Koskenniemi's proposition for international law? Apart from all kinds of epistemological consequences, the most important is perhaps the recognition that "institutions do not carry the good 
society with themselves". ${ }^{6}$ This implies in turn that law can never replace politics, since formalism as such as neutral and does not take stance between competing political interests and needs. This does not however deny judicial or legal activism as shown most aptly in the chapter discussing the work of Hersch Lauterpacht. The model of good society, the notion of liberty chosen need however to be defined through public discourse. ${ }^{7}$

It can be argued that the line of thought in Koskenniemi's recent book is very much within what could be termed as "the Finnish school" of current legal philosophy which seems to be returning to an effort to reconceptualize and reinvigorate the Rechtsstaat ('rättsstaten', 'the rule of law') within the broad framework of legal positivism. ${ }^{8}$ In the year 2000, Kaarlo Tuori published in Finnish his excellent study on Critical Legal Positivism, discussing the basis of rationality, validity and legitimacy of modern law. ${ }^{9}$ The core point is that the validity criteria of legal norms include both formal validity (observance of legally regulated procedure for law enactment and logical consistency) as well as normative legitimacy (justifiability in the light of the morally - and ethically - laden principles of the law's "subsurface layers"). The public discourse, to which lawyer's need to be, and are, participating provide us with the "normative deep structure", examples of which are human-rights principles and the principle of democracy. On this point there is considerable convergence between Tuori and Koskenniemi. I also dare argue that works like those of Susan Marks or Kaarlo Tuori and the current issues forming part of the (anti-)globalization debate and touching upon the concepts of accountability, participation and democratic legitimacy (even if they are disguised and partly neutralized as "governance") are very much putting international law in the very heart of "the global game", contradicting Koskenniemi's argument about the marginalization of international law. From a Finnish, American, or for that matter a Swedish, perspective perhaps this is the case, but it seems that for those involved in the on-going constitutional and political reform in Kenya or Uganda, or those affected by the huge projects of the World Bank in many parts of the world, this is not so. ${ }^{10}$

There are huge numbers of -isms reviewed in Koskenniemi's book. They cover a broad spectrum ranging from fundamental intuitions 
such as "optimism" and "pessimism" through to enormously complex and controversial notions such "liberalism" and "cosmopolitanism". The emphasis on "intuitions", "sensibilities" and "emotional dispositions" can be viewed not only as the heritage of post-modern constructivist thinking, but also a clear stand against a view of law as verifiable science. Even though Habermas is hardly mentioned, and even though elements of Habermas's deliberation theory can be viewed as only a faint background against which Koskenniemi's analysis is canvassed, Koskenniemi's thesis is an indirect rejection of the justificatory role of "truth" or any transcendental value.

\section{International Liberalism and Its Limits}

I will now comment on only one of all the -isms, with regard to which I perceive that there are some problematic assumptions in the book. Koskenniemi begins his book with a discussion on the development and entrenchment of the "liberal ideas", "liberal sympathies", "liberal politics", "liberal constitutionalism" of the "men of 1873", i.e. the members and supporters of the Institut de droit international which held its first meeting in Ghent in the year of 1873. Liberalism is through out the work opposed to conservatism and it is closely associated to progress and humanitarianism, or solidarity as was the case in France (see chapter 4).

The problem is that internationally oriented liberalism has had and still has many faces. ${ }^{11}$ This is indirectly recognized by Koskenniemi himself when he points out the association of liberalism and nationalism in late 19th century. Currently the ambivalence of liberalism is most clearly seen with regard to international economic relations. Traditionally, and ever since Adam Smith and John Stuart Mill, economic liberty is a major component of liberal thinkers. Protection of property and free market economy are crucial preconditions of individual liberty and this was indeed the basis of American Realism of which Myres McDougal was a part long before he founded the New Haven school at Yale. ${ }^{12}$ Therefore, we are indeed in great trouble balancing on the one hand global free trade and free movement of goods, services and persons with cultural values and 
human rights (such as right to decent education) or with the prevention of environmental degradation on the other. The ambivalence of what is usually termed as liberalism is also obvious with regard to the perennial issue of war. Kant's view, for instance, was that war can help establish and strengthen republics. Others have argued that war can be justified in the name of self-determination or against tyranny. Another strand of liberalism has been committed pacifists automatically condemning the use of any form of violence. ${ }^{13}$ Liberalism and cultural difference is another uneasy alliance. Most contemporary liberal thinkers - including Rawls and Kymlicka accept and institutionally accommodate reasonable difference. Unreasonable difference is contained through reference to adjudication, preferably through a constitutional law. Law and courts are crucial for such thinking as a limit not only of the power of the state but equally of all groups not accepting the dominant liberal paradigm. If this is crucial for domestic liberal thinking it is even more so for international liberalism, where the scope of difference and "unreasonableness" may be all the greater. Koskenniemi does not offer us any further clue of how to solve this dilemma. Indeed he seems to think that "maybe the time of synthesis is not yet here". ${ }^{14}$

I believe however, that there are attempts for such synthesis. Not so much from the part international lawyers, but still within the realm of law - and post-modernism learned us that the distinction of national and international is to a large extent a fiction - as evidenced by David Dyzenhaus last chapter in Legality and Legitimacy - Carl Schmitt, Hans Kelsen and Hermann Heller in Weimar. ${ }^{15}$ Dyzenhaus's main argument is that while liberalism and democracy are an uneasy couple, they are possible to combine if the distinction of the private and the public is not essentialized and public discourse is comprehensive. The rationality of legality can never be looked at as compensation or the limit of the irrational forces of politics. Dyzenhaus accepts Habermas's emphasis on public deliberation and a culture of political justification as well as his primacy of democracy over liberalism. ${ }^{16}$ He rejects however - as does Koskenniemi Habermas's transcendentalism and argues, following Hermann Heller, that the moral value that law serves is the value of collective selfgovernment so that any claim of the good life, also a non-liberal one, is part of the scope of open democratic deliberation. There are no 
questions automatically put outside the realm of politics. On this point he departs from liberals such as Rawls, Kymlicka and perhaps also Habermas. He also concludes that such a thesis requires that institutions of legality, which I here take to cover the whole legal profession and much more, need to be answerable to principles of accountability and participation and to ever changing ideals of social equality. If the agenda of international law encompasses such goals, and it seems to me that it does, then it has not lost its transformative force. Such a position would have important consequences for our responses to the issue, for instance, of the constitutionalization of the European sphere. The call for constitutionalization should never entail the marginalization of politics.

\section{Is International Law Truly Depoliticized?}

Whether international law is truly depoliticized, and thereby deprived of all its reformist power, is another matter of debate. Koskenniemi, reminds us that the Spanish Civil War (1936-1939) diveded European intelligentsias for the first time in uniformly right-left positions. This division became quite apparent, even though perhaps not as uniformly, as evidenced by the internal division of the Labour Party in the United Kingdom, with regard to the recent war against Iraq, in the spring of 2003. Indeed, a big part of the pleasure of reading the book is this sense of déja vu with regard to the legal arguments chosen and their structure. Koskenniemi cites Le Fur who characterized the Spanish Civil War as a "struggle between the Christian civilization and atheistic communism, or more briefly, ... , between civilization and barbarism" in the same way as arguments had been used to describe the Franco-German adversity in the First World War. ${ }^{17}$ Later on, the same line of thinking was used to explain and justify the invasion by the US in the Dominican Republic (1965). The Legal Adviser of the State Department, L.C. Meeker, asserts the general right to use military force by the United States in the Western hemisphere (my emphasis) against "foreign ideologies", which made "communism" equivalent to "armed attack" under Art. 51 of the United Nations Charter. ${ }^{18}$ Wolfgang Friedmann and other critics of 
the intervention are dismissed by the State Department as "legal fundamentalists". Those were in fact the exact words used by conservative Swedish politicians about legal criticism against the war in Iraq in the spring of 2003; "legalism" was presented as the opposite of "humanitarianism" and "democratic efforts".

\section{Open Themes}

The main theme of the book is, as we have already - but only indirectly - seen, the constant struggle and balancing between universalism and particularism; inclusion and exclusion; the internal (as in Kelsen's legal rationality) and the external (sociological, theological, political etc) view on law. Within this wider context Koskenniemi makes ample reference to the impact of religious assumptions and beliefs - mainly concerning Protestantism, Catholicism and Zionism/Jewish beliefs. The interplay between religion and international law is indeed an unexplored field pointed out to us by Koskenniemi.

Very many of the men discussed in chapters 1-5 are extensively discussed in terms of family relations, friends, religion, education, and professional careers.

Here I think that there is a bias in the treatment of different personalities discussed in the book. While there is extensive, in many cases even exaggerated detail with regard to scholars active before the Second World War, there is much less discussion, contextuality and situational placement of those appearing after World War II. So, while there is always a more or less sympathetic explanation of the positions taken by Gustave Rolin-Jaequemyns or John Westlake, fairly little is said on later American scholars. I would think that if the current "culture of dynamism" among American lawyers is a true challenge, we would need to understand much more profoundly the background and development of this culture. For instance there is no discussion or contextualization of Wolfgang Friedmann's opponents such as professors Adolf A. Berle or A.J. Thomas. Nor is there any similar analysis of the more contemporaries such as Myres McDougal, Anne-Marie Slaughter, Thomas Franck or Ferdinand 
Tesón. Even though one can easily appreciate the difficulty of portraying one's contemporaries, this leaves us with a sense of imbalance and wonder. Admittedly the formal end of analysis is 1960, the last part of chapter 6 and the epilogue deal, however, as much with near past and even the present and future of international law. Now, if there is a critique of the unhistorical American international law jurisprudence, which I think is part of Koskenniemi's argument, this then needs to be addressed in a direct way. ${ }^{19}$ How has this "culture of dynamism" developed? Which are its premises? Who are its driving forces? What is the role of professional organizations such as the American Bar Association or the American Society of International Law? Does legal education support this culture? What is the relation between international law and religion in American international legal jurisprudence? My guess is that we will now start witnessing articles and books touching upon such themes, not only with regard to the situation in the US, but in many parts of the world. This would be a not so unexpected development in the aftermath of critical, reflexive thinking.

I can also see another theme silently permeating the book, even if it is only indirectly addressed by Koskenniemi; that of the double roles of many of the protagonists involved in his historical exposé. Westlake, Descamps, Scelle, Bourgeois, Politis, to take but some of the names, were all of them both successful academics and at the same time committed politicians. Are those positions that can be reconciled if one argues for a "culture of formalism"? In the same vein, is it possible to reconcile an academic career with positions such as that of a legal adviser to government? What are the preconditions and results of such combination? Earlier, Koskenniemi has advocated a relativistic view on this. In his comment to the Symposium on Method organized by the American Society of International Law he wrote that "what works as a professional argument depends on the circumstances". The different "styles" lawyers use, such as "academic theory" or "professional practice" are not hierarchically related and "the final arbiter of what works is nothing other than the context (academic or professional) in which one argues". ${ }^{20}$ While Koskenniemi tries to present this as an issue of simple stylistic difference, one can argue that his examples (especially with regard to the legitimation of colonial imperialism) of the gap 
between principled academic reasoning and applied political decision making, by the very same people, does not support such a relaxed approach. As Koskenniemi aptly put it: no style is neutral. ${ }^{21}$

\section{Notes}

${ }^{1}$ Koskenniemi, pp. 2-3.

${ }^{2}$ Chapter 2 (dealing with imperialism), chapter 5 on Lauterpacht and chapter 6 on Schmitt, Morgenthau and international relations have appeared earlier in journals and books in the period 1997-1999. This makes each chapter an independent entity which can be read and convey its message irrespective of the totality, something which can be seen as a considerable advantage in a book of more than 500 pages.

${ }^{3}$ Koskenniemi, p. 4.

${ }^{4}$ Ibid., p. 515.

${ }^{5}$ Koskenniemi, p. 500.

${ }^{6}$ Ibid., p. 176.

${ }^{7}$ Public discourse is only momentarily mentioned in the final pages of the book. The reference to the transformative potential and the need for human rights and democracy - democracy as an open, non-universalistic notion -seem to be closely connected to Susan Marks argument in The Riddle of All Constitutions (OUP, 2000). Marks argues that the predominant democracy formula of present international law represents a rather conservative low-intensity democracy.

${ }^{8}$ There are many examples of this school in the recent Fogelklou, Anders $\&$ Spaak, Torben (eds.), Festskrift till Åke Frändberg, Iustus förlag, Uppsala, 2003.

${ }^{9}$ The English edition, Critical Legal Positivism, came out in 2002 and Tuori extends his thankfulness to, i.a. Martti Koskenniemi, for discussions on the earlier Finnish edition.

${ }^{10}$ One can simply mention authors such as Yash Gai, Joe Oloka-Onyango and Makau wa Mutua who are both criticizing the hypocritical faces of international legal argumentation, as well as making use of it both nationally and internationally.

${ }^{11}$ This is a criticism shared by Rein Müllerson in his book review of the book in vol. 13, no. 3 of the European Journal of International Law, 727.

${ }^{12}$ Cf. Alexander, Gregory S., Comparing the Two Realisms - American and Scandinavian, 50 American Journal of Comparative Law 131-174 (2002).

${ }^{13}$ Howard, Michael, War and the Liberal Conscience (1986). 
${ }^{14}$ Koskenniemi, p. 516.

${ }^{15}$ Dyzenhaus book came out at OUP in 1997.

${ }^{16}$ At about the same time Quentin Skinner came out with his Liberty before Liberalism, CUP, 1998.

${ }^{17}$ Koskenniemi, p. 339.

${ }^{18}$ Ibid., p. 413. See also the similar words chosen by professors Berle and Thomas, ibid. pp. 497-500.

${ }^{19}$ For an effort to address the same issue with regard to English (leaving in reality aside the American part) analytical jurisprudence, see Morton J. Horwitz, Why is Anglo-American Jurisprudence Unhistorical? In 17 Oxford Journal of Legal Studies 551-583 (1997).

${ }^{20}$ Koskenniemi, M., Letter to the Editors of the Symposium, in 93 American J. Int. Law 351-361 (1999), at 356.

${ }^{21}$ Ibid. at 361. 